\title{
Microbiological assessment of the cervix in patients with Infertility
}

\author{
Maad M. Shalal* \\ Alaa K. Khalaf** \\ Shaymaa K. Jasim*
}

\author{
FICOG \\ MBChB \\ FICOG, CABOG
}

\begin{abstract}
:
Background: Diagnostic laparoscopy is the standard procedure performed as the final test in the infertility work up before progressing to infertility treatment, but it was found that laparoscopy may increase the risk of pelvic infection which is one of the causes of infertility either in men or women.

Fac Med Baghdad

2017; Vol.59, No.2

Received: Dec. 2016

Accepted: June 2017

Objectives: To assess the cervix microbiologically in patients who were planned to have diagnostic laparoscopy as part of infertility investigations.

Patients and methods: A cross sectional study done at department of obstetrics \& gynecology, Baghdad teaching hospital, Medical city, Baghdad, Iraq in 2013, over a period of 7 months, cervical swabs were taken from 30 women complaining of infertility, just before diagnostic laparoscopy was done for them. For these swabs; gram stain, culture for bacteria, PCR (polymerase chain reaction) technique for detection of Chlamydial infection, and direct microscopical examination for Trichomonal infection were done.

Results: We noticed higher percentage of cervical infections in patients who had past history of cervical cauterization, dilatation and curettage and / or hysterosalpingography.

Conclusion: Cervical swab for bacteriology before any uterine instrumentation should be done as a routine investigation.
\end{abstract}

Key words: Microbiological assessment, cervix, laparoscopy.
Introduction:

More recent studies with adequate anaerobic techniques demonstrated the predominance of Lactobacillus and Bacteroides species in the cervical flora, and that anaerobes are often involved in infections of the female genital tract. It is likely that these organisms belong to the normal cervical and vaginal flora. (1-3)

Chlamydia: Chronic chlamydial infection may affect female upper genital tract leading to secondary tubal infertility, pelvic inflammatory disease (PID), chronic pelvic pain, salpingitis and ectopic pregnancies. (4)

Gonorrhea: is a sexually transmitted infection caused by Gram-negative diplococci, named Neisseria gonorrhea. Trans luminal spread of Neisseria gonorrhea may occur, causing PID (pelvic inflammatory disease), $(<10$ percent $)$ and epididymo-orchitis $(<1$ per cent $)$ in men. (5)

Trichomonal infection: Transmission is almost exclusively sexual in adults. It can be acquired perinataly and occur in 5 per cent of babies born to infected mothers. (6)

Uterine Instrumentation Procedures that increase the risk of infection: Dilatation and curettage $(D \& C)$ : is a therapeutic gynecological procedure as well as a rarely used method of first trimester abortion. $(7,8)$

* Dept. of Obstetrics and Gynecology/College of Medicinel University of Baghdad, Corresponding Email:shaimaa79kadhim@yahoo.com.

** Baghdad Teaching Hospital.

Hysterosalpingography (HSG): is a radiologic procedure to investigate the shape of the uterine cavity with the shape and patency of the fallopian tubes. (911)

Intrauterine devices (IUCD): Intrauterine devices (IUD) are small devices, often ' $T$ '-shaped, usually containing either copper or levonorgestrel, which are inserted into the uterus through the cervix. $(12,13)$

Diagnostic Laparoscopy: provides a minimally invasive option for thorough evaluation of the peritoneal cavity and pelvic organs. It is often performed to evaluate pelvic pain or causes of infertility, to diagnose endometriosis, or to ascertain the extent of adhesive disease or even the qualities of a pelvic mass. (14)

\section{Patients and methods}

This cross-sectional study was done in Baghdad teaching hospital from the first of June till the end of December in 2013.

Patients' selection: Cervical swabs were taken from 30 infertile women (with primary or secondary infertility) just before they have done laparoscopy. Verbal consent was taken from all women included in the study, only one patient refused to take the sample from her.

Our study included infertile patients taking in consideration a history of either 2-5 years or more than 5 years of marriage, with past history of cervical cauterization, dilatation and curettage, and hyserosalpingography.

With the patients in lithotomy position under aseptic technique, a speculum was inserted in the vagina, and endoscervical swabs were taken just before laparoscopy. 
Three swabs were taken for:

A. Chlamydia detection by PCR (polymerase chain reaction), multiplex PCR assay, done in central health laboratory.

B. Direct microscopical examination to exclude trichomnus vaginalis.

C. Gram stain and culture (crystal violet media, addition of iodide, rapid decolorization with ethanol or acetone, and counterstaining with safranin)).

Chlamydial infections were diagnosed through two steps: first DNA extraction was done then PCR (polymerase chain reaction).

Direct microscopical examination was performed to detect trichomonus vaginalis with Gram stain and culture of the cervical swabs.

Samples were collected in laparoscopic department in Baghdad teaching hospital; while patients were in the follicular phase of the cycle.

Statistical analysis: Analysis of data was carried out using the available statistical package of SPSS-20 (Statistical Packages for Social Sciences- version 20), data were presented in simple measures of frequency, percentage, mean, standard deviation, and range (minimum-maximum values). The significance of difference of different percentages (qualitative data) were tested using chi-square test $\left(\chi^{2}\right.$-test $)$ with application of Yet's correction or Fisher Exact test whenever applicable. Statistical significance was considered whenever the $\mathrm{P}$ value was equal or less than 0.05 .

\section{Results:}

The current study was conducted on 30 infertile patients before performing laparoscopic procedure. Their mean age was $31.3 \pm 3.7$ years ranging from 26 to 38 years with majority of them below 35 years of age (80\%). Regarding parity, 21 (70\%) of patients were nulliparous and 9 were para one and two (30\%), 21 (70\%) of them had primary infertility and $9(30 \%)$ with secondary infertility.

It was found that 14women (46.7\%) undergone laparoscopy were married for 2-5 years while 16 $(53.3 \%)$ were married for 5 years and more. In addition to that; $11(36.7 \%)$ of them had undergone cervical cauterization for various reasons, $6(20 \%)$ had history of dilatation and curettage mainly for missed abortion or blighted ovum. The majority of patients 27 (90\%) had undergone hysterosalpingography previously as part of investigations for infertility.

The direct microscopical examination of cervical swabs revealed higher infection rates (pus cells 10 and more), $9(30 \%)$ with $(+), 10(33.3 \%)$ with $(++), 5(16.7 \%)$ with $(+++)$, and $2(6.7 \%)$ with $(++++)$ pus cells; as shown in Table 1 .
Table 1: Results of direct microscopical examination of the cervical swabs

\begin{tabular}{llll}
\hline Direct exam & & No & $\%$ \\
\hline No & \multicolumn{1}{l}{$\%$} & - \\
\cline { 2 - 4 } Few & 4 & 13.3 \\
\cline { 2 - 4 } Pus cells & $(+)$ & 9 & 30.0 \\
\cline { 2 - 4 } & $(++)$ & 10 & 33.3 \\
\cline { 2 - 4 }$(+++)$ & 5 & 16.7 \\
\cline { 2 - 4 }$(++++)$ & 2 & 6.7 \\
\cline { 2 - 4 } & Mean \pm SD(Range) & $17.5 \pm 10.8$ & $(2-40)$
\end{tabular}

$(+)=10$ pus cells/high power field

The same picture was seen regarding gram stain for cervical swab; $(73.3 \%)$ were with pus cells (10 and more).

The bacteriological Gram stain results of the cervical swabs showed that $(70 \%)$ of samples had bacterial growth from whether gram negative $(46.7 \%)$ or gram positive $(23.3 \%)$, as explained in figure 1

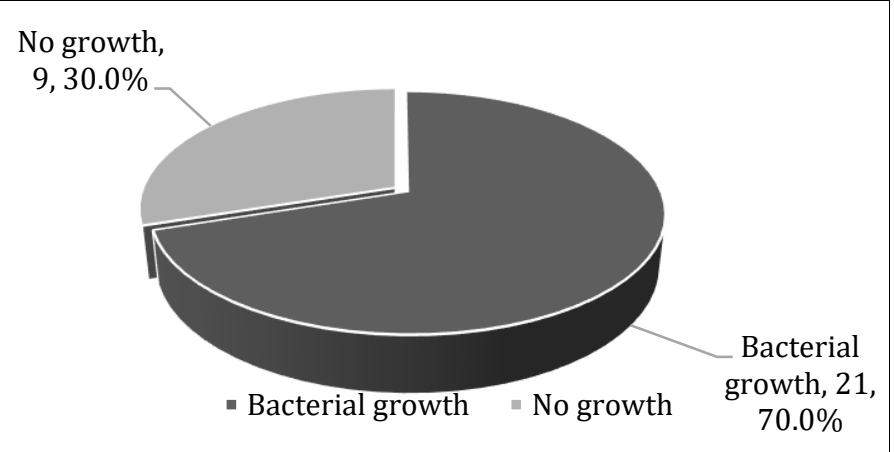

Figure 1: Rate of bacterial growth by culture.

When culturing the swabs for those with positive bacterial growth (21 samples), using MacConkey agar for Gram-negative bacteria, and Hekton enteric agar for Gram-positive bacteria to differentiate between different types of bacteria, the results obtained where a growth of $\beta$ hemolytic streptococci isolates from 7 patients $(23.3 \%)$, Escherichia. Coli isolated from 6 patients (20\%), Klebsiellae from 5 patients (16.7\%) and from 3 patients $N$. gonorrhea was isolated as it is shown in table 2 
Table 2: the types of bacteria isolates by culture.

\begin{tabular}{lll}
\hline Bacterial isolates by culture & No. & \% \\
\hline No growth & 9 & 30.0 \\
\hline Bacterial growth; & 21 & 70.0 \\
\hline$\beta$ hemolytic streptococci & 7 & 23.3 \\
\hline E. coli & 6 & 20.0 \\
\hline Klebsiellae & 5 & 16.7 \\
\hline N.gonorrhea & 3 & 10.0 \\
\hline
\end{tabular}

Regarding other types of infection, the results obtained showed that 2 samples $(6.7 \%)$ were positive for $T$. vaginalis, (by direct microscopical examination) and 14 samples (46.7\%) were positive for Chlamydia (by $\mathrm{PCR}$ ) as illustrated in figure 2 \&figure 3

T. vaginalis

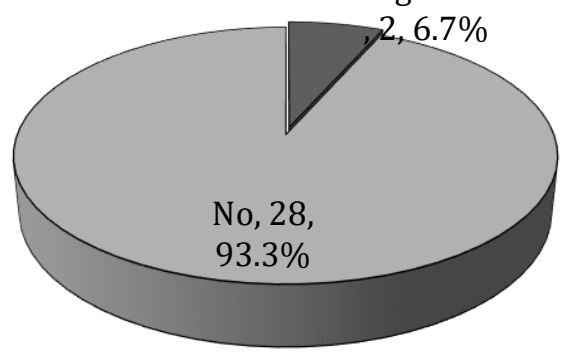

Figure 2: Rate of Tichomonusvaginalis infection

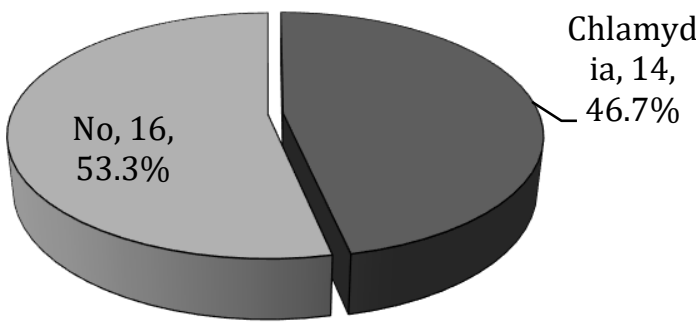

Figure 3: Rate of Chlamydia trachomatis infection

In the current study, we tried to link the positivity of Chlamydial infection with other investigation like gram stain bacteriological examination and culture results in addition to Trichomonal infection. There was a high positivity rate of bacterial growth in association with Chlamydial infection (78.6\%) more with gram negative stained bacterial than gram positive stained bacteria (64.3\% Vs. 14.3\%) and for different types of bacterial isolates ( $\beta$ hemolyticstreptococci2 isolates, E. coli isolates, Klebsiellae3 isolates and 3 isolates with $\mathrm{N}$. gonorrhea).While $\mathrm{T}$. vaginalis show a low positivity rate with Chlamydial infection (7.1\%).
These results although had a variation in the findings but the difference in the percentages did not reach the level to be significant statistically $(\mathrm{P}=0.191,0.251 \&$ 0.922 respectively).

We tried to find if there was a link between history of Chlamydial, Trichomonal and bacterial infections with duration of marriage in years; as shown in Table 3, there was an increase in the percentage of Chlamydial infections in women who were married for $=>5$ years, but there was no increase in the percentage of Trichomonal or bacterial infections. That results although had a variation in the findings but the difference in the percentages did not reach the level to be significant statistically ( $\mathrm{p}$ value $=0.696$ ).

Table 3: Relationship between duration of marriage with bacterial and Trichomonal infections

\begin{tabular}{|c|c|c|c|c|c|c|}
\hline \multirow{2}{*}{\multicolumn{2}{|c|}{ Bacterial properties }} & \multicolumn{4}{|c|}{ Years of marriage } & \multirow{3}{*}{$\begin{array}{l}\mathrm{P} \\
\text { value } \\
*\end{array}$} \\
\hline & & \multicolumn{2}{|l|}{$2-5$} & \multicolumn{2}{|l|}{$\Rightarrow>5$} & \\
\hline & & No & $\%$ & No & $\%$ & \\
\hline \multirow[t]{4}{*}{$\begin{array}{l}\text { Gram } \\
\text { stain }\end{array}$} & No growth & 4 & $\begin{array}{l}28 . \\
6\end{array}$ & 5 & $\begin{array}{l}31 . \\
3\end{array}$ & 0.815 \\
\hline & $\begin{array}{l}\text { Bacterial } \\
\text { growth }\end{array}$ & 10 & $\begin{array}{l}71 . \\
4\end{array}$ & 11 & $\begin{array}{l}68 . \\
7\end{array}$ & \\
\hline & G-ve & 6 & $\begin{array}{l}42 . \\
9\end{array}$ & 8 & $\begin{array}{l}50 . \\
0 \\
\end{array}$ & \\
\hline & G+ve & 4 & $\begin{array}{l}28 . \\
6\end{array}$ & 3 & $\begin{array}{l}18 . \\
8\end{array}$ & \\
\hline \multirow{6}{*}{$\begin{array}{l}\text { Bacterial } \\
\text { isolates } \\
\text { by culture }\end{array}$} & No growth & 4 & $\begin{array}{l}28 . \\
6 \\
\end{array}$ & 5 & $\begin{array}{l}31 . \\
3\end{array}$ & \\
\hline & $\begin{array}{l}\text { Bacterial } \\
\text { growth }\end{array}$ & 10 & $\begin{array}{l}71 . \\
4\end{array}$ & 11 & $\begin{array}{l}68 . \\
7 \\
\end{array}$ & \\
\hline & $\begin{array}{l}B \text { hemolytic } \\
\text { strept }\end{array}$ & 4 & $\begin{array}{l}28 . \\
6 \\
\end{array}$ & 3 & $\begin{array}{l}18 . \\
8\end{array}$ & \\
\hline & E coli & - & - & 6 & $\begin{array}{l}37 . \\
5\end{array}$ & \\
\hline & Klebsiellae & 4 & $\begin{array}{l}28 . \\
6 \\
\end{array}$ & 1 & 6.3 & \\
\hline & $\begin{array}{l}\text { N.gonorrhoe } \\
a\end{array}$ & 2 & $\begin{array}{l}14 . \\
3\end{array}$ & 1 & 6.3 & \\
\hline \multirow{2}{*}{$\begin{array}{l}\mathrm{T} \text {. } \\
\text { vaginalis }\end{array}$} & Positive & 1 & 7.1 & 1 & 6.2 & 0.922 \\
\hline & Negative & 13 & $\begin{array}{l}92 . \\
9\end{array}$ & 15 & $\begin{array}{l}93 . \\
8\end{array}$ & \\
\hline \multirow[t]{2}{*}{$\begin{array}{l}\text { Chlamydi } \\
\text { a }\end{array}$} & Positive & 6 & $\begin{array}{l}42 . \\
9 \\
\end{array}$ & 8 & $\begin{array}{l}50 . \\
0 \\
\end{array}$ & 0.696 \\
\hline & Negative & 8 & $\begin{array}{l}57 . \\
1\end{array}$ & 8 & $\begin{array}{l}50 . \\
0\end{array}$ & \\
\hline
\end{tabular}

In table 4, there was an increase in the percentage of bacterial growth in patients who had history of cervical cauterization. Also there was an increase in the percentage of Chlamydial infection in addition.

Although that results had a variation in the findings, but the difference in the percentages did not reach a level to be significant statistically ( $\mathrm{P}$ value $0.08,0.0156$ respectively). 
Table 4: Relationship between history of cervical cauterization with bacterial and trichomonal infections

\begin{tabular}{|c|c|c|c|c|c|c|}
\hline \multirow{2}{*}{\multicolumn{2}{|c|}{ Bacterial properties }} & \multicolumn{4}{|c|}{ Cervical cauterization } & \multirow{3}{*}{$\begin{array}{l}\mathrm{P} \\
\text { value* }\end{array}$} \\
\hline & & \multicolumn{2}{|c|}{ Positive } & \multicolumn{2}{|c|}{ Negative } & \\
\hline & & No. & $\%$ & No. & $\%$ & \\
\hline \multirow[t]{4}{*}{ Gram bacilli } & No growth & 2 & 18.2 & 7 & 36.8 & 0.089 \\
\hline & $\begin{array}{l}\text { Bacterial } \\
\text { growth }\end{array}$ & 9 & 81.8 & 12 & 63.2 & \\
\hline & G-ve & 8 & 72.7 & 6 & 31.6 & \\
\hline & $\mathrm{G}+\mathrm{ve}$ & 1 & 9.1 & 6 & 31.6 & \\
\hline \multirow{6}{*}{$\begin{array}{l}\text { Bacterial } \\
\text { isolates by } \\
\text { culture }\end{array}$} & No growth & 2 & 18.2 & 7 & 36.8 & 0.212 \\
\hline & $\begin{array}{l}\text { Bacterial } \\
\text { growth }\end{array}$ & 9 & 81.8 & 12 & 63.2 & \\
\hline & $\begin{array}{l}\text { B hemolytic } \\
\text { strept }\end{array}$ & 1 & 9.1 & 6 & 31.6 & \\
\hline & $E$ coli & 4 & 36.4 & 2 & 10.5 & \\
\hline & Klebsiellae & 3 & 27.3 & 2 & 10.5 & \\
\hline & N.gonorrhoea & 1 & 9.1 & 2 & 10.5 & \\
\hline \multirow[t]{2}{*}{ T. vaginalis } & Positive & 1 & 9.1 & 1 & 5.3 & 0.685 \\
\hline & Negative & 10 & 90.9 & 18 & 94.7 & \\
\hline \multirow[t]{2}{*}{ Chlamydia } & Positive & 7 & 63.6 & 7 & 36.8 & 0.156 \\
\hline & Negative & 4 & 36.4 & 12 & 63.2 & \\
\hline
\end{tabular}

*Significant positivity using Pearson Chi-square test at 0.05 level.

Again, we worked hard to see if there was any link between the rate of cervical Bacterial Trichomonal and Chlamydial infections with previous history of dilatation and curettage (because of missed abortion or blighted ovum). There was an increase in the percentage of bacterial infections (both gram -ve bacteria (50\%) and gram +ve bacteria (33.3\%)). Even that results had some sort of discrepancy, but the differences were not statistically significant.

There was an increase in the percentage of bacterial and Trichomonal infections with a history of hysterosalpingography, but these results were not significant from the statistical point of view.

\section{Discussion:}

It is clear that infections with different organisms can affect the fertility potential of couples in the reproductive age. $(15,16)$ In this study, we have assessed the cervix from microbiological point of view in 30 infertile ladies just before they had undergone laparoscopy. We discovered that $46.7 \%$ of the women were positive regarding chlamydial infection assessed by PCR (polymerase chain reaction) technique done for cervical swab, these results were similar to that appeared in a study done in United Kingdom which found that $43 \%$ of infertile patients were positive for Chlamydial infection by PCR. (16) While other studies from India showed lower rates of chlamydial infections, which were $27 \%$ (17), and $18.6 \%$. (18) E. Coli results were positive in $20 \%$ of patients, but Momoh AR and colleagues from Nigeria who put down a percentage of $6.88 \%$ did not agree that. (19) We found that $\mathrm{N}$. gonorrhea were positive in $10 \%$ of patients, compared to $1.02 \%$, which was declared by a study done in Turkey. (20) Talking about Klebsiella, it was found in $16.7 \%$ of patients, while it was $5.63 \%$ in the above Nigerian article. (19) Another bacteria that we saw in cervical examination is T.vaginalis, with a percentage of $6.7 \%$, and if we take a look at the work done in Egypt by ElShazly AM and her team, we may see more than a double of our results as they stated a percentage of $14.6 \%$. (21) The variations in the prevalence of infections that appeared between our results and others may be due to many causes, such as differences in sample size, differences in the level of sexual education among the population (i.e.: how to protect against sexually transmitted diseases), and / or a high prevalence of poor hygiene

High rates of infections could be due to the selection of a high-risk group of patients (i.e. infertile patients). Also, we noticed that there was an increase in the percentages of cervical infections in patients who had a past history of cervical cauterization, dilatation and curettage and / or hysterosalpingography, (although these were statistically not significant). This may be explained in two ways, either because these women already had had infections, which may constitute a risk of introducing infections higher in the genital tract, and that could be a co-factor for their infertility or due to a contamination of surgical instruments.

\section{Conclusion:}

Cervical swab for bacteriology before any uterine instrumentation, including laparoscopy, dilatation and curettage, and / or intrauterine device, should be performed as a routine investigation, so that to avoid any complications that may happen after these procedures, and to give the chance of management accordingly for the patient and her partner (after his assessment of course). That should be recommended before planning for any uterine invasive procedure.

\section{Author's contributions:}

Alaa Kamel: Iraqi board student who performed the study protocol including patient selection, examination, and doing concerned tests.

Maad Mahdi: Supervisor, helped the student in data collection and interpretation.

Shaymaa Kadhim: data analysis and critical revision. 


\section{References:}

1. Daftrey S, Chakravarti S. Manual of obstetrics. Manual of obstetrics. 2011. 74 p.

2. Lurie S, Asaala H, Harari OS, Golan A, Sadan $O$. Uterine cervical non-gonococcal and non-chlamydial bacterial flora and its antibiotic sensitivity in women with pelvic inflammatory disease: Did it vary over 20 years? Isr Med Assoc J. 2010;12(12):747-50.

3. Smith WL, Hedges SR, Mordechai E, Adelson ME, Trama JP, Gygax SE, et al. Cervical and vaginal flora specimens are highly concordant with respect to bacterial vaginosis-associated organisms and commensal Lactobacillus species in women of reproductive age. J Clin Microbiol. 2014;52(8):307881.

4. Machado ACS, Guimarães EMB, Sakurai E, Fioravante FCR, Amaral WN, Alves MFC. High titers of Chlamydia trachomatis antibodies in Brazilian women with tubal occlusion or previous ectopic pregnancy. Infect Dis Obstet Gynecol. 2007;2007.

5. Fox C. Mosby's medical, nursing and allied health dictionary (6th edition). Vol. 10, Accident and Emergency Nursing. 2002. p. 113.

6. Brooks GF, Carroll KC, Butel JS, Morse SA, Mietzner TA. Microbiologia Médica de Jawetz, Melnick \& Adelberg - 26.ed. [Internet]. Microbiologia Médica de Jawetz, Melnick \& Adelberg - 26.ed. 2014. 872 p. Available from: https://books.google.com/books?id=QbPrBgAAQBAJ \&pgis $=1$

7. Ali SF, Ayub S, Manzoor NF, Azim S, Afif M, Akhtar $N$, et al. Dilatation and Curettage. Am Coll Obstet Gynecol [Internet]. 2010;5(6):2. Available from: http://www.pubmedcentral.nih.gov/articlerender.fcgi? artid $=2883573 \&$ tool $=$ pmcentre $\&$ rendertype $=$ abstrac $t$

8. Yarandi F, Izadi-Mood N, Eftekhar Z, Shojaei H, Sarmadi S. Diagnostic accuracy of dilatation and curettage for abnormal uterine bleeding. J Obstet Gynaecol Res. 2010;36(5):1049-52.

9. Baramki T a. Hysterosalpingography. Fertil Steril [Internet]. 2005;83(6):1595-606. Available from: http://www.ncbi.nlm.nih.gov/pubmed/15950625

10. Fernández-Sola C, Martínez-Caba MI, Hernández-Padilla JM, Carmona-Samper E, GraneroMolina J. Experiences of Spanish women undergoing hysterosalpingography as part of the infertility process: A phenomenological study. J Clin Nurs. 2016;25(34):494-504.

11. Hindocha A, Beere L, O’Flynn H, Watson A, Ahmad G. Pain relief in hysterosalpingography. Cochrane database Syst Rev. 2015;9:CD006106.

12. Winner B, Peipert JF, Zhao Q, Buckel C, Madden T, Allsworth JE, et al. Effectiveness of long-acting reversible contraception. $N$ Engl $J$ Med. 2012;366(21):1998-2007.

13. Hsia JK, Creinin MD. Intrauterine Contraception. Semin Reprod Med. 2016;34(3):175-82.

14. Udwadia TE. Diagnostic laparoscopy. [Internet]. Vol. 18, Surgical endoscopy. 2004. p. 6-10. Available from: http://www.ncbi.nlm.nih.gov/pubmed/12958680 15. Mania-Pramanik J, Donde UM, Maitra A. Use of polymerase chain reaction (PCR) for detection of Chlamydia trachomatis infection in cervical swab samples. Indian J DermatolVenereolLeprol. 2001;67(5):246-50.

16. Barlow REL, Cooke ID, Odukoya O, Heatley MK, Jenkins $J$, Narayansingh $G$, et al. The prevalence of Chlamydia trachomatis in fresh tissue specimens from patients with ectopic pregnancy or tubal factor infertility as determined by PCR and in-situ hybridisation. J Med Microbiol. 2001;50(10):902-8.

17. Mania-PramanikJ, Kerkar S, Sonawane S, Mehta $P$, Salvi V. Current Chlamydia trachomatis infection, a major cause of infertility. $J$ Reprod Infertil. 2012;13(4):204-10.

18. Kokkayil P, Rawre J, Malhotra N, Dhawan B. Coinfection of Mycoplasma genitalium and Chlamydia trachomatis in an infertile female patient with genital tuberculosis. Indian J Pathol Microbiol [Internet]. 2013;56(4):457-9. Available from: http://www.ncbi.nlm.nih.gov/pubmed/24441248

19. Momoh ARM, Idonije, Nwoke EO, Osifo, Okhai O, Omoroguiwa, et al. Pathogenic bacteria-a probable cause of primary infertility among couples in Ekpoma. J Microbiol Biotechnol Res Sch Res Libr J Microbiol Biotech Res [Internet]. 2011;1(3):66-71. Available from: http://scholarsresearchlibrary.com/archive.html 20. Eksi F, Dikensoy E, Gayyurhan ED, Balci I, Balat $O$, Karsligil $T$, et al. The prevalence of Chlamydia trachomatis and Neisseria gonorrhoeae in the endocervical swab specimens of symptomatic, asymptomatic and infertile women in Turkey. Arch Gynecol Obstet. 2011;283(6):1349-55.

21. El-Shazly AM, El-Naggar HM, Soliman M, ElNegeri M, El-Nemr HE, Handousa AE, et al. A study on Trichomoniasis vaginalis and female infertility. J Egypt Soc Parasitol. 2001;31(2):545-53. 